\title{
Developing a Records and Information Management Model for Oil Marketing Companies in Zambia Based on the Records Cycle Model
}

\author{
Sharon Malake1, Jackson Phiri² \\ ${ }^{1}$ Graduate School of Business, University of Zambia, Lusaka, Zambia \\ ${ }^{2}$ Department of Computer Sciences, School of Natural Sciences, University of Zambia, Lusaka, Zambia \\ Email: smalake@yahooh.com, Jackson.phiri@cs.unza.zm
}

How to cite this paper: Malake, S., \& Phiri, J. (2020). Developing a Records and Information Management Model for Oil Marketing Companies in Zambia Based on the Records Cycle Model. Open Journal of Business and Management, 8, 1870-1887. https://doi.org/10.4236/ojbm.2020.84114

Received: June 16, 2020

Accepted: July 27, 2020

Published: July 30, 2020

Copyright $\odot 2020$ by author(s) and Scientific Research Publishing Inc. This work is licensed under the Creative Commons Attribution International License (CC BY 4.0).

http://creativecommons.org/licenses/by/4.0/

\section{(c) (i) Open Access}

\begin{abstract}
The success of any organization is dependent upon effective records management practice that ensures the right records are availed when needed for effective operation. An effective records management system facilitates the flow of records throughout an organization to ensure that information is available readily where and when it is needed. However, studies have shown that many organizations are still faced with challenges in records management. Studies have also shown that delayed retrieval of active records, management policy, up-to-date records retention and disposal schedule and guidelines for managing electronic records were among the notable challenges. This study therefore, was aimed at identifying the challenges faced by oil marketing companies in Zambia in records management. Specifically the study sought to develop a model in order to address the identified challenges. The study utilized purposive nonprobability sampling with closed ended researcher administered questionnaire. A total of 151 questionnaires were administered with a response rate of 53\%. The primary data obtained from the questionnaires was analyzed using statistical package for social sciences (SPSS) and Chi-square tests were conducted to establish the level of independence between variables. The study revealed that, these companies face challenges such as, lack of retention and disposal schedule, lack of proper storage facility and security issues of the records. The study has also shown that the organization has no formal records management programs in place. It is therefore been realized that the organizations need a better, more efficient and more uniform way of creating, sorting, storing and destroying the records. In filing, bar code scanners should be introduced to make identification and storage of records easier. These will also help to improve the man-
\end{abstract}


agement control and security aspect of records management and address most of these challenges faced by oil marketing companies.

\section{Keywords}

Oil Marketing Companies, Records Cycle Model, Records Management, Zambia

\section{Introduction}

Oil Marketing Companies are companies that operate in the petroleum industry. The companies distribute, market petroleum products and lubricants in Zambia. There are several Oil Marketing Companies that operate in Zambia. Among them are: Puma Energy, Mt Meru and Total Zambia. Oil Marketing Companies are involved in the creation of records in their processes of business activities. The companies receive and generate volumes of records often available for employees to update or familiarize themselves with the normal operation and also to run the organization efficiently. The business also keeps records to fulfill legal requirements for their operations and protect the rights of stakeholders. For instance in Zambia a company has to keep records for a certain period of time in compliance with the requirement of tax and other regulatory documents. The success of any organization is dependent upon an effective records management practice that ensures the right records are availed when needed for effective operation.

Organizations are accountable in many ways to meet legal, regulatory and fiscal requirements. They undergo audits and inspections or provide explanations for what was done (Shepherd \& Yeo, 2003). Organizations ought to adhere to proper records management practices in order to ensure good public service delivery. Without reliable and authentic documentary evidence underpinning all essential accountability processes, organizations cannot ensure transparency, guarantee accountability or allow for the exercising of good governance (Obura, 2012). The primary function of records management is to facilitate the flow of records throughout an organization to ensure that information is available rapidly where and when needed. Unless records are managed efficiently, it is not possible to conduct business, to account for what has happened in the past or to make decisions about the future. To carry out these functions require an efficient, effective records management program and practices.

\section{Literature Review}

An organization receives and processes tremendous amount of information day in day out but not all of them are records. In order to define records management, the concept "record" needs to be fully explored. A record is defined either in terms of the physical tangible format in which it appears, or in terms of the 
information it contains. It must be noted that records differ in format or size and have different contents, any definition of records is a pragmatic one. The definition change with the passage of time and as the profession gets involved in more complex issues. Records can be defined as any recorded information or data in any physical format or media created or received by an organization during its course of official business and kept as evidence of policies, decisions, procedures, functions, activities and transactions.

All records pass through a lifecycle. Basically, the record is created, actively used for a time, and then stored in case of queries or other referrals before it is too old to be of any further use. At that point it should either be destroyed or transferred to an archive as part of the permanent record of the organization. Langemo (1995) defines records management as the professional management of information in the physical form the time records are received or created through their processing, distribution and placement in a storage and retrieval system until either eventual elimination or identification for permanent retention in the archives. Records management can also be defined as a function of providing control of records from creation, or receipt through their processing, distribution, organization, storage and retrieval to their ultimate disposal (Kennedy \& Schunder, 1994).

An organization receives and processes tremendous amount of information day in day out but not all of them are records. In order to define records management, the concept "record" needs to be fully explored. A record is defined either in terms of the physical tangible format in which it appears, or in terms of the information it contains. It must be noted that records differ in format or size and have different contents, any definition of records is a pragmatic one. The definition change with the passage of time and as the profession gets involved in more complex issues. Records can be defined as any recorded information or data in any physical format or media created or received by an organization during its course of official business and kept as evidence of policies, decisions, procedures, functions, activities and transactions.

All records pass through a lifecycle. Basically, the record is created, actively used for a time, and then stored in case of queries or other referrals before it is too old to be of any further use. At that point it should either be destroyed or transferred to an archive as part of the permanent record of the organization. Langemo (1995) defines records management as the professional management of information in the physical form the time records are received or created through their processing, distribution and placement in a storage and retrieval system until either eventual elimination or identification for permanent retention in the archives. Records management can also be defined as a function of providing control of records from creation, or receipt through their processing, distribution, organization, storage and retrieval to their ultimate disposal (Kennedy \& Schunder, 1994). 


\subsection{Records Creation}

At the beginning of any records management process is the creation of the record. There are many ways to create business records. These may include; sending or receiving an email, creating a spreadsheet or document, or receiving a document from outside the organization. Contracts, budgets, bank statements, policy manuals and meeting minutes are all things that can be considered records. An organization should determine which documents created or received during business processes should be captured as records into a record keeping system and how long they should be maintained within the system based on the analysis of the legal and regulatory environment, business and accountability requirements and the risks of not capturing or retaining the records.

\subsection{Records Type}

Emmerson (1999) argues that there are four types of record businesses that you can work with and they are named according to their use. These records are; vital records (records that cannot be replaced), important records (those that can easily be transferred to inactive record), useful records (day to day business records) and non-essential records (records of no future value). Records could be grouped according to their function, in this case, records could be active or inactive (Cage, 2012). The activeness of each record determines how to rate the record or how to dispose it.

\subsection{Record Storage and Maintenance}

One sure sign that an organization has an effective records management program in place is that it stores and maintains its records securely and efficiently. Records should be stored in such a manner so as to facilitate user access and ensure that they are protected from unauthorized access, use, disclosure, removal, deterioration, loss or destruction. Records storage requirements have been indicated in various studies including those of Obura (2012). Record storage is important in a small or large organization. This is because each document/record has its own value especially on the business of the company.

\subsection{Record Access and Retrieval}

Organizations create, retain, and preserve records so that they can be used. If a user cannot locate a document, it might as well be non-existence. As such, an effective records management program should have in place systems; manual or automated, that can locate and retrieve records in a reliable and timely fashion to meet the needs of users.

\subsection{Record Retention/Disposal}

Proper record retention and disposition is the key to an effective records management program. It ensures that records are present when needed for litigation, 
audits, day-to-day business purposes, or historical research, but that unneeded records do not take up costly storage space. At the heart of a legally compliant records management program is the records retention schedule. The policy guides on how long records are supposed to be kept and when to be disposed. This serves as the platform for protecting organizational records as well as the best method to avoid litigations and to control records program costs. According to Kennedy and Schauder (1994) records retention schedules enable organizations to meet regulatory requirements and control the costs of records storage through disposing records at the end of their business life. Records disposition refers to the actions that are associated with implementing decisions about the retention or destruction of records. It also includes migration and transfer of records to new storage locations, custodians or owners.

\subsection{Benefits of Proper Records Management in Organizations}

Records management is important because it supports an organization to make decisions based on evidence, meet operational, legal and regulatory requirements. Records management is also important as it supports an organization to be open and accountable, enhance operational efficiency and effectiveness. The importance of records management is increasingly being recognized by organizations (Sanderson \& Ward, 2003). It is therefore the responsibility of records managers to ensure that they gain the attention of decision-makers in their organizations. Gaining recognition is all about convincing management of the role of records management as enabling unit in an organization.

Yosuf and Chell (1999) pointed the following as benefits of accurate records management; speedy and accurate retrieval of records, necessitates systematic filing and storage of records, saves space and prevents duplication of effort with similar records, easier retrieval, better utilization of space, and less frequent loss of documents were pointed as benefits of accurate records management.

Records management is important because it reduces litigation risks, provides regulatory compliance and protects corporate assets (Porter-Roth, 2006). According to Blake (2014) properly managed records can help reduce operating expenses, enhance customer service and ensure that the company is in compliance with laws and regulations. Without records, no assessment can be made of whether individuals, private and public organizations have actually carried out the actions and transactions that they had to execute, whether they ensure that these actions and transactions meet the criteria of efficiency, legitimacy or the principles of good governance and whether they had done things which that were not supposed to do (Thomassen, 2001).

\subsection{Challenges in Records Management}

Mohammed et al. (2018) argue that records management in the institution is challenged by improper records management; inadequate proper security for records; inadequate professionally trained records managers; there are inade- 
quate resources to facilitate proper records management practices in the institution; insufficient space for records management; misplacement of vital records in the institution; loss of vital records in the institution; inadequate computer terminals; lack of record keeping policy; lack of record retention; lack of disposition schedule in the institution; ineffective means of retrieving record; improper records management in the institution. The management of the institution should consider the findings of the study and address these challenges for proper records management and the benefits associated with such benefits.

A study conducted by international journal of academic research in accounting, finance and management science on records management and organization performance in Ghana reviewed that most organizations had no formal records management programs in place. The government and other private businesses kept records in whatever form they felt appropriate without the benefit of retention schedules, disposition guidelines or other formal information life cycle procedures (Tagbotor et al., 2015). It was therefore realized that most organizations needed a better, more efficient and more uniform way of creating, sorting, storing and destroying the records. This led to the formulation of new registrations, which required that businesses needed to start retaining for certain periods. In filing, bar codes scanners were introduced to make identification and storage of records easier. These also helped to improve the management control and security aspect of records management.

\subsection{Oil Marketing Companies}

The oil marketing companies are in a diversity business of distribution and retailing of petroleum products. Oil and Gas companies not only have to ensure compliance with multiple agencies in multiple jurisdictions, they also must ensure compliance across multiple disciplines. Information trail of record keeping is cardinal at all levels as it might be required by the users; Statutory boards such as ZRA is an institution board that value record keeping and give emphasis to its client on how important to keep records, the organization advise client to keep records for TAX Audit especially on import documents. Therefore, along with maintaining a growing volume of files, leases and facility documents, oil and gas companies have a complex compliance standard to maintain within the energy sector. Ensuring timely access to all records and information, following the legally defensible destruction procedures can be challenging, further complicated by mergers, acquisitions, and divestitures and over-evolving laws and regulations.

The importation, distribution and selling of petroleum products involve the creation, maintenance and preservation of documents by the companies to run the business effectively. Documents such as; Delivery note, Invoices, Importation documents-bill of lading, Purchase order, Credit note, Legal documents, Contracts between parties etc. are created and preserved to act as evidence.

\section{Records life cycle model}


Records life cycle refers to the stages of a record's life span that is, from its creation to its preservation in an archives or disposal (Figure 1).

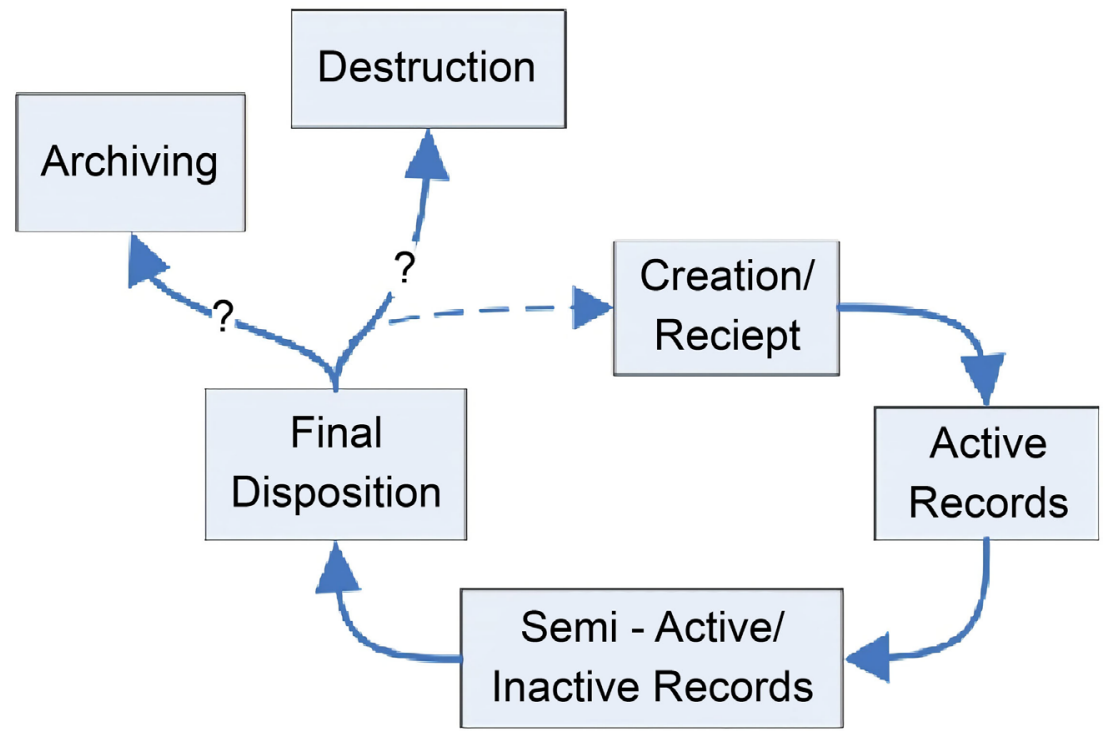

Figure 1. Record life cycle. Source: The record lifecycle an own interpretation of GNTW (2002).

\subsection{Related Works}

Quite a number of works have been carried out on records management and its contributions to the organization.

Seniwoliba et al. (2017) conducted a study on the challenges of records management in higher education in Ghana. The primary aim of this study was to find out whether records management as a valuable source of the institution receives the desired attention. The research design approach was used for this study. Primary data in this research was collected through the use of questionnaires while the secondary data was gathered from books, publications and public records. Two sampling methods were used in the study to select the respondents one probability and the other none probability namely, simple random sampling and quota sampling respectively. The study reviewed that records management decentralized and are managed manually through filling of hard copies in folders and kept in metal cabinets based on individual ability and knowledge in departments.

Phiri (2009) conducted a study that examined records management in the public service and its impact on the payment of pension benefits at the public service pension fund. The study revealed that the public service had neglected the management of personnel records. However, it was found that the public service had adequate policies and procedure in the management of records but the implementation of these was lacking. Documents were often missing in personnel records and files were not always easy to retrieve leading to delayed payment of pension benefits. 
Another study conducted by Unegbu and Adenike (2013) on the challenges of records management practices in the ministry of information and strategy in Nigeria. Data was collected through questionnaires and 35 of the respondents filed the questionnaire. Collected data was analyzed using SPSS analytical package and reported in discrete figures, percentages and two hypotheses were tested using Chi-square at 0.05 degree of significance. The findings of this study were that effective implementation of records management practices positively enhances organizational performance and that proper records management practices positively bring about easy decision making in the organization.

Adewale et al. (2016) also carried out a research on the assessment of records management practices in selected local government councils in Nigeria. The study adopted the descriptive survey research method using questionnaires for data collection. Its population comprised 415 records of personnel in the selected councils, of which 208 were using simple random technique. Descriptive statistics were used for the analysis of this data, the results indicated that paper records were a dominating medium for recording/conveying information in the councils with most of these being either in active state, semi-active and vital records. Records were kept and maintained in the registry while in active records were kept in the records store. It was also discovered that the storage facilities for record keeping were insufficient.

Adu (2014) assessed the records management practices among the administrative staff of University of Education. Both primary and secondary data were used in this study; primary data was collected through questionnaire administration while secondary data was collected from the Internet and journals. A non-probability sampling method specifically purposive sampling was used to come up with a sample. Statistical package for social sciences (SPSS) was used to analyze the data. The study revealed that the administrative documents are stored in both manual and electronic forms. This leads to quick decision-making, saves office space and promotes good corporate governance. The study also revealed that there were insufficient resources in terms of professionally trained records managers, training starved administration staff and office space.

Bake (2015) investigated the contribution of records management towards an organization's competitive performance in case of commercial banks in Ethiopia in order to find how records management contributes to organization's competitive survival. Survey study design was used to conduct this research. Primary and secondary data collection methods were used and data analysis was through descriptive statistics, using graphs and bar charts. Interviews and questionnaires were the instruments for this research. The results of the study showed that records management plays a great role in ensuring the development of the bank and record is a major resource of the bank. Information is key resource in today's world. No organization can be competitive without the use of information in its operation. 


\section{Methodology}

The study used descriptive and quantitative research design (Creswell, 2013). According to Trochim (2006), quantitative research often translates into the use of statistical analysis to make the connection between what is known and what can be learned through research, whereas qualitative is defined as a study, which is conducted in a natural setting (Creswell, 2013). Population refers to the total number of units from which data can be collected such as individuals, artifacts, events or organizations. In this study, the population comprised of 151 employees from three top Oil Marketing Companies in Zambia. Purposive sampling technique was used in this study. In purposive sampling the researcher only chooses those participants that are fit for the study, that are capable of providing relevant information. The method for purposive sampling is fairly straight forward, all a researcher must do is reject the individuals who do not fit a particular profile when creating the sample. Participants were chosen based on their seniority. It was assumed that the more senior and longer a position one holds the much relevant information one is likely to give. Primary data was collected by use of semi-structured questionnaire. The questionnaire had five parts; Demographic data, record creation/receipt, Records maintenance and preservation, Records access/use and assessing the record management practices. A total of 151 questionnaires were distributed to Oil Marketing Companies out of which a positive response on 80 were receives for analysis. The researcher considered this a success since it represented $52.9 \%$ or $53 \%$ of the sample size. A response rate of $50 \%$ is adequate, any response rate not exceeding $60 \%$ and greater than $50 \%$ is good, and a response rate above $69 \%$ is very high (Mugenda \& Mugenda, 2003). Secondary data were obtained from literature review of similar studies. The study used SPSS to analyze data collected. The Chi-square test of independence was used in the statistical analysis of results. Figure 2 shows the model adapted from the Records Cycle Model in Figure 1 that was used in this study. It highlights the relations between 4 variables; records creation, use, storage and disposal to records management practices.

\section{Results}

In this section basic statistical results of data collected are presented and analyzed in the context of the existing knowledge reviewed under literature review. Frequency tables and graphs are presented on the data that was collected.

\subsection{Basic Statistical Analysis}

In this study, chi-square test of independence will be used. The Chi-Square test of independence is used to determine if there is a significant relationship between two nominal (categorical) variables. The frequency of each category for one nominal variable is compared across the categories of the second nominal variable. 


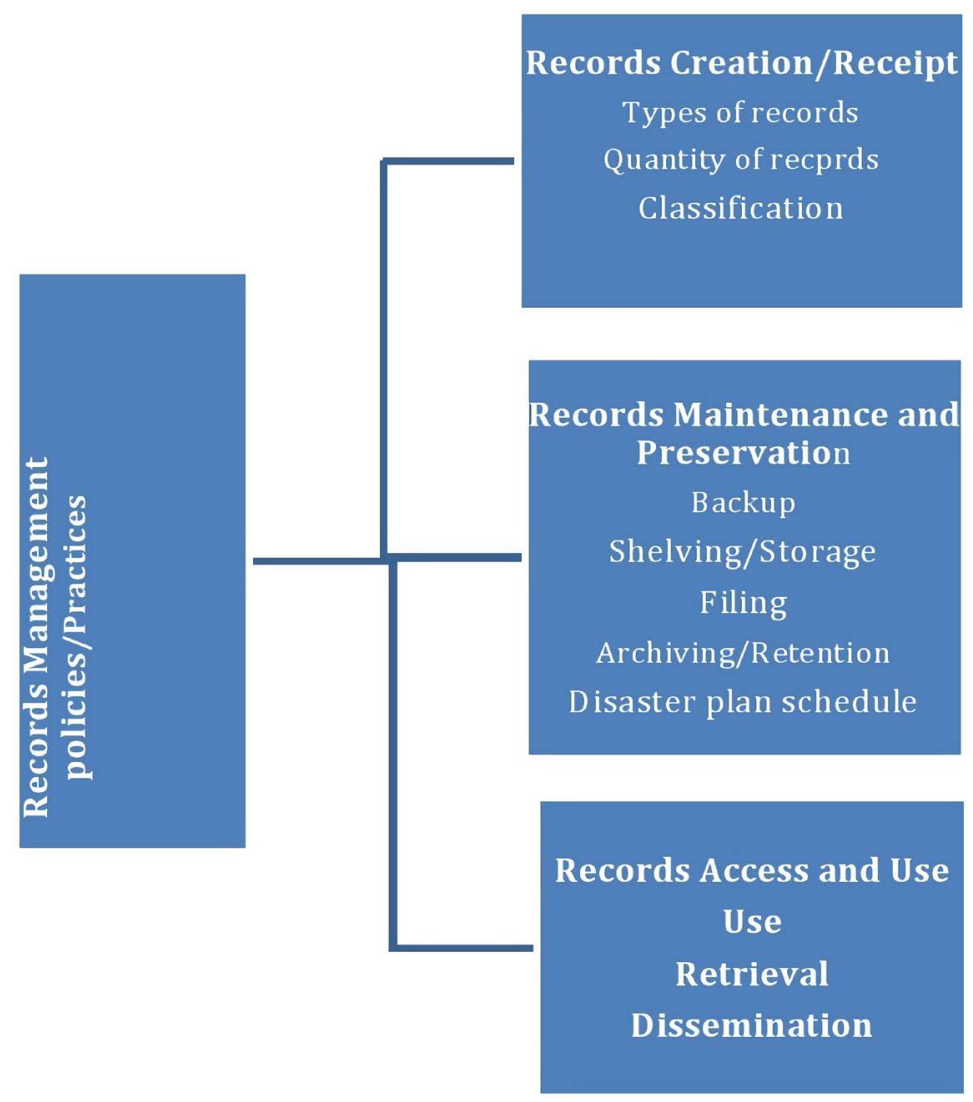

Figure 2. The proposed research model.

The research sought to establish if both gender were well represented in the study, as shown in Figure 3, both gender were well represented in the sample with a higher number of males who represented $82 \%$ of the sample against $18 \%$ for females.

In order to evaluate the reliability of the questionnaire responses, the researcher sought to establish the respondents' education level. As shown in Table $1,82.5 \%$ of the respondents have been through tertiary education. This implies that most of the respondents were qualified enough to understand and complete the questionnaire. $15 \%$ of the respondents have been through secondary school and only $2.5 \%$ did not specify their qualification.

The study sought to establish the number of years the respondents have been working in the company. The obtained data were analyzed as shown in Table 2. The study established that 26 of the respondents have been working in the company for $1-5$ years, followed by those who been with the company for a period range of 6 - 10 years with 24 respondents. Those with an experience of between $11-15$ years and above 16 years account for 21 and 8 respondents respectively with 1 none response rate. From the findings therefore, majority of the respondents were experienced and hence can highly be informative on issues that relate to records management.

Statistical Tests of Independence 


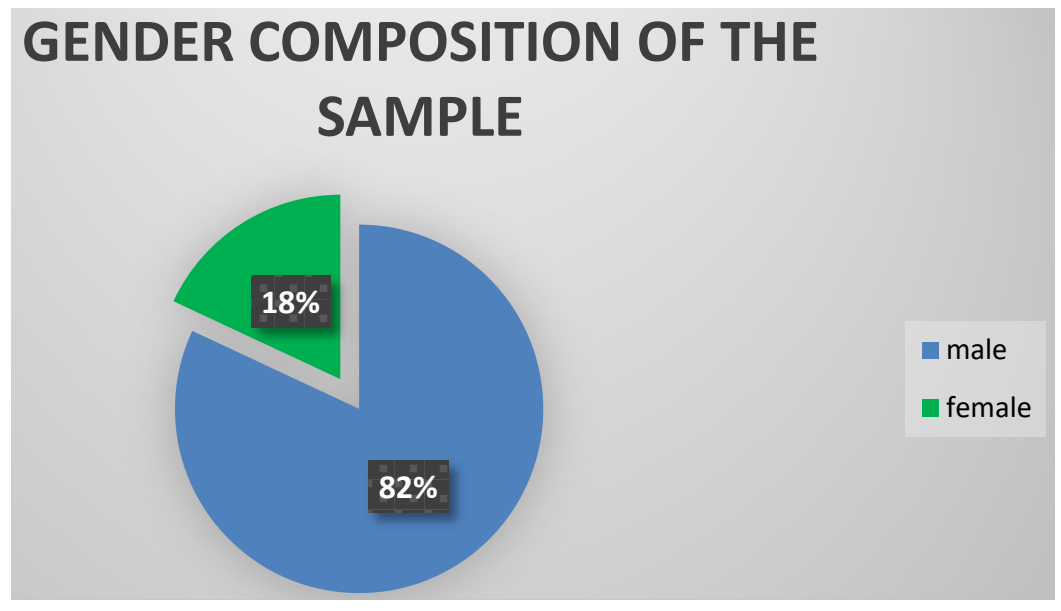

Figure 3. Distribution of study sample by gender. Source: survey results.

Table 1. Distribution of study sample by education level.

\begin{tabular}{lccccc}
\hline \multicolumn{5}{c}{ What is your level of education? } \\
\hline & Frequency & Percent & Valid Percent & Cumulative Percent \\
\hline \multirow{4}{*}{ Valid } & Secondary & 12 & 15.0 & 15.4 & 15.4 \\
& College & 36 & 45.0 & 46.2 & 61.5 \\
& University & 30 & 37.5 & 38.5 & 100.0 \\
\multirow{3}{*}{ Missing } & Total & 78 & 97.5 & 100.0 & \\
& None response & 2 & 2.5 & & \\
& Total & 80 & 100.0 & & \\
\hline
\end{tabular}

Source: survey results.

Table 2. Distribution of study sample by length of service.

\begin{tabular}{cccccc}
\hline \multicolumn{5}{c}{ How many years have you worked in this company? } \\
\hline & Frequency & Percent & Valid Percent & Cumulative Percent \\
\hline & $1-5$ years & 26 & 32.5 & 32.9 & 32.9 \\
Valid & 6 - 10 years & 24 & 30.0 & 30.4 & 63.3 \\
& $11-15$ years & 21 & 26.25 & 26.6 & 100.0 \\
& 16 and above yeas & 8 & 10.0 & 10.1 & \\
Tissing & Total & 79 & 98.8 & 100.0 & \\
& None response & 1 & 1.25 & & \\
\hline
\end{tabular}

Source: survey results.

1) Record management policies/practices VS records creation/receipt;

2) Record management policies/practices VS records maintenance and preservation;

3) Record management policies/practices VS records access and use. 
Table 3 shows the guideline on what to create. The survey results show that 55 representing $68.8 \%$ of the respondents indicate that there are guidelines on what records to create while 19 representing $23.8 \%$ indicates that there are no guidelines on what to create.

Table 4 shows a cross tabulation between an employee's knowledge of record creation/receipt and the company's policies and procedures on the creation of records.

\section{Statement of hypothesis:}

H0: The Company's policies and procedures for creating and storing records have no influence on employees' knowledge of records management

H1: The Company's policies and procedures for creating and storing records have an influence on employees' knowledge of records management

\begin{tabular}{|c|c|c|c|}
\hline & \multicolumn{3}{|c|}{ Chi-Square Tests } \\
\hline & Value & Df & Asymp. Sig. (2-sided) \\
\hline Pearson Chi-Square & $1.305^{\mathrm{a}}$ & 3 & 0.728 \\
\hline
\end{tabular}

Conclusion: observed $P$-value (0.728) is greater than the significance level of 0.05 , hence the test is insignificant and we fail to reject the null hypothesis and conclude that The Company's policies and procedures for creating and storing records have no influence on employees' knowledge of records management.

The survey results indicate that 68 representing $85 \%$ of the respondents indicate that they file their materials on a regular basis and only $10(12.5 \%)$ of the respondents do not file their newly created materials in a regular basis. 2 representing $2.5 \%$ of the respondents did not respond (Table 5).

Table 6 is a cross tabulation between the Company's policies and procedures for creating/receiving records and filing of new materials.

\section{Statement of hypothesis:}

H0: The Company's policies and procedures for creating and storing records have no influence on filing of new materials.

H1: The Company's policies and procedures for creating and storing records have an influence on filing of new materials.

\begin{tabular}{|c|c|c|c|}
\hline & \multicolumn{3}{|c|}{ Chi-Square Tests } \\
\hline & Value & Df & Asymp. Sig. (2-sided) \\
\hline Pearson Chi-Square & $4.866^{\mathrm{a}}$ & 3 & 0.182 \\
\hline
\end{tabular}

Conclusion: Observed $P$-value (0.182) is greater than the significance level of 0.05 , hence the test is insignificant and we fail to reject the null hypothesis and conclude that there is not enough evidence to suggest an association between the Company's policies/procedures for creating and storing records and filing of new materials. 
Table 3. Guidelines on what records to create.

\begin{tabular}{cccccc}
\hline \multicolumn{5}{c}{ Are there guidelines on what records to create? } \\
\hline \multirow{4}{*}{ Valid } & Yes & 55 & 68.75 & 74.3 & 74.3 \\
& No & 19 & 23.75 & 25.7 & 100.0 \\
\multirow{3}{*}{ Missing } & Total & 74 & 92.5 & 100.0 & \\
& \multirow{2}{*}{ None response } & 6 & 7.5 & & \\
& & & & & \\
\end{tabular}

Source: survey results.

Table 4. Records management policies/practices vs Records creation/receipt.

\begin{tabular}{|c|c|c|c|c|c|c|}
\hline & & \multicolumn{4}{|c|}{$\begin{array}{l}\text { The company has policies and procedures } \\
\text { for creating and receiving records in both } \\
\text { paper and electronic format. }\end{array}$} & \multirow[t]{2}{*}{ Total } \\
\hline & & $\begin{array}{l}\text { Strongly } \\
\text { Disagree }\end{array}$ & Neutral & Agree & $\begin{array}{l}\text { Strongly } \\
\text { Agree }\end{array}$ & \\
\hline $\begin{array}{l}\text { Do you as an employee in the oil } \\
\text { marketing company know what }\end{array}$ & Yes & 2 & 12 & 9 & 44 & 67 \\
\hline information to create and capture? & No & 0 & 1 & 2 & 4 & 7 \\
\hline Total & & 2 & 13 & 11 & 48 & 74 \\
\hline
\end{tabular}

Source: Research results analysis using Pearson chi-square test and $P$-value.

Table 5. Filing of materials.

\begin{tabular}{lccccc}
\hline \multicolumn{5}{c}{ Do you file your new materials on a regular basis? } \\
\hline \multirow{4}{*}{ Valid } & Yes & Frequency & Percent & Valid Percent & Cumulative Percent \\
& No & 68 & 85.0 & 87.2 & 87.2 \\
\multirow{2}{*}{ Missing } & Total & 10 & 12.5 & 12.8 & 100.0 \\
& None Response & 2 & 97.5 & 100.0 & \\
& Total & 80 & 100.0 & & \\
\hline
\end{tabular}

Source: survey results.

Table 6. Records management policies/practices vs Records maintenance and preservation.

\begin{tabular}{|c|c|c|c|c|c|c|}
\hline & & \multicolumn{4}{|c|}{$\begin{array}{l}\text { The Company's policies and procedures for creating and } \\
\text { receiving records in both paper and electronic format. }\end{array}$} & \multirow{2}{*}{ Total } \\
\hline & & Strongly Disagree & Neutral & Agree & Strongly Agree & \\
\hline Do you file your new & Yes & 2 & 8 & 10 & 43 & 63 \\
\hline materials on a regular basis? & No & 0 & 4 & 1 & 5 & 10 \\
\hline Total & & 2 & 12 & 11 & 48 & 73 \\
\hline
\end{tabular}

Source: Research results analysis using Pearson chi-square test and $P$-value.

Table 7 shows the accessibility and use of documents. The study results show that 52 representing $65 \%$ of the respondents said their files are accessible by any 
on while the minority 26 (32.5\%) of the respondents said their files are not accessed easily by anybody. The conclusion of the findings is that documents are stored in places where they are easily accessed.

Table 8 shows a cross tabulation between storage of records and Organization's data and Security policy.

\section{Statement of hypothesis}

HO: Record management practices have no Influence on the accessibility of records.

H1: Record management practices have an Influence on the accessibility of records.

\begin{tabular}{cccc}
\hline \multicolumn{4}{c}{ Chi-Square Tests } \\
\\
\hline Value & Df & Asymp. Sig. (2-sided) \\
\hline Pearson Chi-Square & $13.423^{\mathrm{a}}$ & 4 & 0.009 \\
\hline
\end{tabular}

Conclusion: According to the Chi-square test above, the observed $P$-value (0.009) is less than the significance level of 0.05 , hence the test is significant and we reject the null hypothesis and conclude that there is evidence to suggest, the Company's Record management practices have an influence on the accessibility of records.

Table 9 shows the retention of documents. 28 out of the total number of respondents strongly agree to say their company has a thorough documentation retention schedule. 19 agree to the statement while 20 were not sure whether their company has the retention schedule or not. 3 out of the total number of respondents disagreed while 4 strongly disagree to say their company has a record retention documentation schedule. This indicates that Oil Marketing Companies have a document retention schedule in place, which helps these organizations to ensure records are retained for as long as they are needed.

Table 10 shows a cross tabulation between disposal by archiving and the company's record retention schedule.

\section{Statement of hypothesis:}

H0: The Company's record management practices have no influence on how inactive records are preserved.

H1: The Company's record management practices have an influence on how inactive records are preserved.

\begin{tabular}{cccc}
\hline \multicolumn{4}{c}{ Chi-Square Tests } \\
\\
\hline Value & Df & Asymp. Sig. (2-sided) \\
\hline Pearson Chi-Square & $10.933^{\mathrm{a}}$ & 4 & 0.027 \\
\hline
\end{tabular}

Conclusion: According to the Chi-square test above, the observed $P$-value $(0.027)$ is less than the significance level of 0.05 , hence the test is significant and 
Table 7. Accessibility of records.

\begin{tabular}{|c|c|c|c|c|c|}
\hline \multicolumn{6}{|c|}{ Are your documents stored in place where they can be easily accessed by anyone? } \\
\hline & & Frequency & Percent & Valid Percent & Cumulative Percent \\
\hline & Yes & 52 & 65.0 & 66.7 & 66.7 \\
\hline \multirow[t]{2}{*}{ Valid } & No & 26 & 32.5 & 33.3 & 100.0 \\
\hline & Total & 78 & 97.5 & 100.0 & \\
\hline \multirow[t]{2}{*}{ Missing } & none response & 2 & 2.5 & & \\
\hline & Total & 80 & 100.0 & & \\
\hline
\end{tabular}

Table 8. Records management policies/practices vs Records access and use.

\begin{tabular}{|c|c|c|c|c|c|c|}
\hline & & \multicolumn{5}{|c|}{$\begin{array}{c}\text { The organization adequately addresses } \\
\text { data privacy and security issues }\end{array}$} \\
\hline & & $\begin{array}{l}\text { Strongly } \\
\text { Disagree }\end{array}$ & Disagree & Neutral & Agree & $\begin{array}{l}\text { Strongly } \\
\text { Agree }\end{array}$ \\
\hline $\begin{array}{l}\text { Are your documents stored in } \\
\text { a place where they can be } \\
\text { easily accessed by anyone? }\end{array}$ & $\begin{array}{l}\text { Yes } \\
\text { No }\end{array}$ & 0 & 1 & 3 & $\begin{array}{l}11 \\
2\end{array}$ & $\begin{array}{l}27 \\
12\end{array}$ \\
\hline Total & & 5 & 3 & 6 & 13 & 39 \\
\hline
\end{tabular}

Source; Survey Results analysis using Pearson chi-square test and $P$-value.

Table 9. Records retention schedule.

\begin{tabular}{|c|c|c|c|c|c|}
\hline \multicolumn{6}{|c|}{$\begin{array}{l}\text { A thoroughly documented record retention schedule that lists recorded } \\
\text { categories and expected retention record time period is available in the Company }\end{array}$} \\
\hline & & Frequency & Percent & Valid Percent & Cumulative Percent \\
\hline & Strongly Disagree & 4 & 5.0 & 5.4 & 5.4 \\
\hline \multirow{4}{*}{ Valid } & Disagree & 3 & 3.8 & 4.1 & 9.5 \\
\hline & Neutral & 20 & 25.0 & 27.0 & 36.5 \\
\hline & Agree & 19 & 23.8 & 25.7 & 62.2 \\
\hline & Strongly Agree & 28 & 35.0 & 37.8 & 100.0 \\
\hline \multirow{3}{*}{ Missing } & Total & 74 & 92.5 & 100.0 & \\
\hline & None response & 6 & 7.5 & & \\
\hline & Total & 80 & 100.0 & & \\
\hline
\end{tabular}

Source: survey results.

Table 10. Records management policies/practices vs Records disposal.

\begin{tabular}{ccccccc}
\hline & & \multicolumn{2}{c}{$\begin{array}{c}\text { A thorough documented record retention schedule } \\
\text { that list recorded categories and expected retention } \\
\text { record time period is available in the company. }\end{array}$} \\
\hline $\begin{array}{c}\text { Do you transfer inactive } \\
\text { records to the archives }\end{array}$ & Yes & No & 0 & Strongly \\
Disagree & Disagree & Neutral & Agree & $\begin{array}{c}\text { Strongly } \\
\text { agree }\end{array}$ \\
\hline Total & & 4 & 3 & 5 & 14 & 20 \\
\end{tabular}

Source: Research results analysis using Pearson chi-square test and $P$-value. 
we reject the null hypothesis and conclude there is evidence to suggest, the Company's Record management practices have an influence on how inactive records are preserved.

\subsection{Discussion}

In this study, there is an association between record creation, accessibility/use and preservation. The $p$-values indicate that these variables are not independent of each other and that there is a statistically significant relationship between the categorical variables.

\subsection{Statistical Significant ( $P$-Values)}

All hypothesis tests ultimately use a $P$-value to weigh the strength of the evidence (what the data is telling you about the population). The $P$-value is a number between 0 and 1 and interpreted in the following way: A small $P$-value (typically $\leq 0.05$ ) indicates strong evidence against the null hypothesis, so you reject the null hypothesis. A large $P$-value $(>0.05)$ indicates weak evidence against the null hypothesis, so you fail to reject the null hypothesis. $P$-values very close to the cutoff (0.05) are considered to be marginal (could go either way). Always report the $p$-value so your readers can draw their own conclusions. From this study we are able to see that the $P$-values; $0.009,0.027,(P \leq 0.05)$ as shown in the chi square tests above indicating that these variables are not independent of each other and that there is a statistically significant relationship between the categorical variables.

\section{Conclusion}

The main aim of this study was to develop a model to address challenges faced by oil marketing companies in records management in Zambia. The model used was the Records Cycle Model. The paper adopted descriptive and quantitative research design. The paper used purposive sampling technique because the sample was drawn from a small population of 151 employees of the Oil Marketing Company.

The study revealed that, these companies face challenges such as, lack of retention and disposal schedule and lack of proper storage facility. It was also revealed that the organization does not address security issues of these records for they were kept in areas where any person could access them at any given time. Research model was developed to address the identified challenges.

\section{Recommendations}

There is need for a record retention and disposal schedule to guide these organizations on what documents to keep and for how long.

There is also need for a proper storage facility in which all vital records should be kept and preserved for future use. 
The organizations need a better, more efficient and more uniform way of creating, sorting, storing and destroying the records.

\section{Acknowledgements}

The authors wish to acknowledge all those who took part in the study.

\section{Conflicts of Interest}

The authors declare no conflicts of interest regarding the publication of this paper.

\section{References}

Adewale, A., Abiove, A. A., Olanle, A., \& Issa, W. (2016). An Assessment of Records Management Practice in Selected Local Government Councils in Ogun State, Nigeria. Journal of Information Science Theory and Practice, 4, 49-64.

Adu, F. (2014). Assessment of Records Management Practices among the Administrative Staff of University of Education, Winneba-Kumasi (UEW-K) and Mampong ( $U E W-M$ ) Campuses. Master's Thesis, Kwame Nkrumah University of Science and Technology, Kumasi.

Bake, Z. (2015). The Contribution of Records Management towards an Organization's Competitive Performance in Case of Commercial Bank of Ethiopia Jimma Main Branch.

Blake, R. (2014). Benefits of Records Management. https://www.dummies.com/business/business-strategy/benefits-of-records-management/

Cage, M. (2012). Categories of Records in Records Management.

Creswell, J. W. (2013). Research Design: Qualitative, Quantitative, and Mixed Methods Approaches (4th ed.). Thousand Oaks, CA: SAGE Publications.

Emmerson, P. (Ed.) (1999). How to Manage Your Records: A Guide to Effective Practice. Hemel Hempstead: ICSA Publishing Ltd.

Kennedy, J., \& Schunder, C. (1994). Record Management: A Guide for Students and Practitioners of Records and Information Management. Melbourne: Longman Cheshire.

Langemo, M. (1995). Successful Strategies for Establishing or Strengthening a Record Management Program. In: Proceeding Your Highway in Information Management. ARMA International Annual 40th Year Conference. Pairie Villages, KS: ARMA.

Mohammed, S., Tetteh, R., \& Ahmed Azumah, A. (2018). Challenges Associated with Records Management in Sunyani Technical University. MPRA Paper 89261.

Mugenda, O., \& Mugenda, A. G. (2003). Research Methods: Quantitative and Qualitative Approaches. Nairobi: African Centre for Technology Studies (ACTS) Press.

Obura, O. (2012). Information Practices among SMES in Tororo Direct Uganda. Library Review, 61, 447-469.

Phiri, N. (2009). Records Management in the Public Service and Its Impact on the Payment of Pension Benefits at the Public Service Pension Fund.

Porter-Roth, B. (2006). Applying Electronic Records Management in the Document Management Environment: An Integrated Approach. Polo Alto, CA: XEROX DocuShare Business Unit. 
Sanderson, M., \& Ward, S. (2003). Records Management Mission Critical. Library and Information Update, 1-7 October.

Seniwoliba, A. J., Mahama, A. V., \& Abilla, B. J. (2017). Challenges of Records Management in Higher Education in Ghana: The Case of University for Development Studies. International Journal of Educational Policy Research and Review, 4, 29-41.

Shepherd, E., \& Yeo, G. (2003). Managing Records: A Handbook for Principles and Practices. London: Facet Publishing.

Tagbotor, D. P., Adzido, R. Y. N., \& Agbantu, P. G. (2015). Analysis of Records Management and Organizational Performance. International Journal of Academic Research in Accounting Finance and Management Sciences, 5, 1-16.

Thomassen, T. (2001). A First Introduction to Archival Science. Archival Science, 1, 373-385.

Trochim, W. M. K. (2006). The Qualitative Debate. In Research Methods Knowledge Base. http://www.socialresearchmethods.net/kb/qualmeth.php

Unegbu, V. E., \& Adenike, O. B. (2013). Challenges of Records Management Practices in the Ministry of Information and Strategy, Lagos State, Nigeria. International Research: Journal of Library \& Information Science, 3, 240-263.

Yosuf, Z. M., \& Chell, R. (1999). Core Elements of a Records Management System. Business Archives Principles and Practice, No. 77. 